\title{
History of the East Texas Caddoan/Caddo Research Group, 1996-2008
}

Timothy K. Perttula

Heritage Research Center, Stephen F. Austin State University

Tom Middlebrook

Heritage Research Center, Stephen F. Austin State University

Follow this and additional works at: https://scholarworks.sfasu.edu/ita

Part of the American Material Culture Commons, Archaeological Anthropology Commons, Environmental Studies Commons, Other American Studies Commons, Other Arts and Humanities Commons, Other History of Art, Architecture, and Archaeology Commons, and the United States History Commons

Tell us how this article helped you.

This Article is brought to you for free and open access by the Center for Regional Heritage Research at SFA ScholarWorks. It has been accepted for inclusion in Index of Texas Archaeology: Open Access Gray Literature from the Lone Star State by an authorized editor of SFA ScholarWorks. For more information, please contact cdsscholarworks@sfasu.edu. 
History of the East Texas Caddoan/Caddo Research Group, 1996-2008

Creative Commons License

(c) $($ ) $(9)$

This work is licensed under a Creative Commons Attribution-NonCommercial 4.0 International License 


\title{
History of the East Texas Caddoan/Caddo Research Group, 1996-2008
}

\author{
Timothy K. Perttula and Tom Middlebrook
}

\section{INTRODUCTION}

Recently, the senior author of this article has been working with Hester Davis (Arkansas Archeological Survey) regarding the editing of her manuscript on the history of the Caddo Conference (Davis and Davis 2009), which had its $50^{\text {th }}$ meeting in March 2008 (Lee 2008). In her manuscript she laments the fact that there is very little time being spent by its participants in keeping track of its history: either in the form of transcripts of the meetings, notes on each conference, saving photographs and images, or actively maintaining an archive of materials resulting from each Conference. Davis pointed out that it was important to maintain a record of each Conference, and take steps to do a better job in preserving for others that record for present and future Caddo Conference participants and researchers.

Hester's points, which we agree with, led directly to our discussing the need to put on record a history, as best we can recall it, of the East Texas Caddoan/Caddo Research Group. This informal group has met a number of times since 1996, with the purpose of advancing the general understanding of Caddo archaeology in the East Texas region. The meetings have been held to discuss pertinent and current problems and research issues concerning East Texas Caddo archaeology.

As we recall, the East Texas Caddoan [now Caddo] Research Group (ETCRG) developed out of discussions between Perttula and Middlebrook in January 1996. Middlebrook's own interests in the idea had been piqued by reading the obituary of Fred Plog in the October 1995 American Antiquity (Vol. 60 , No. 4, p. 679) that described his founding of the Southwestern Anthropological Research Group, the success that group had in working together on common research problems, and in working together to improve understandings of the prehistory of the American Southwest. This seemed to both of us like an idea worth emulating for the Caddo archaeological area, or at least the East Texas part of the area since we were more familiar with this region's archaeology and the archaeologists working in that area.

After a phone conversation discussing the possibility of starting a research group, Perttula jotted Middlebrook this note on January 23, 1996:

Dear Tom,

I've been thinking about the formation of an East Texas Caddoan Research Group. Yes, let's definitely do this. As it stands right now, there is no good format to discuss research and archeological issues among a small and knowledgeable set of folks. I like the idea of trying to do this immediately before or after the Caddo Conference. If we attempt to do this for this year, we should talk some more about the agenda, protocol, etc. (One other thing we should do is get a transcript from each meeting).

I have talked with Ross Fields about this, and he agree to be part of the research group. Other people I've thought about as group members are: Jim Corbin, Dee Ann Story, Darrell Creel, Maynard Cliff, Pete Thurmond, Sharon Derrick, Bob Turner, Bo Nelson, Kathy Reese-Taylor, Diane Wilson, Mike Turner.

Let me know what you think. Do other people come to mind?

Tim

Responding on February 5, 1996, Middlebrook sent Perttula this note:

Dear Tim,

... This list looks good to me and I think that we should just go with it. Only 
other names I could come up with may have less direct and immediate interest: Pete Gregory, Jeff Girard, Jim Bruseth, Robbie Brewington, Harry Shafer.

\section{Suggested Outlines for the ETCRG:}

1 Meet twice a year (once associated with the Caddo Conference, and once in the fall) for a minimum of three hours. Fall meeting should be held in East Texas.

2 Gathering to be informal, perhaps around a table.

3 Proceedings taped; edited transcripts to Journal of Northeast Texas Archaeology.

4 The emphasis should be on discussion and interaction relating to hands-on material (artifacts or pre-distributed handouts).

5 The purpose of the meeting will be to advance East Texas Caddoan studies through encouragement of re-evaluating and organizing existing data into testable models of cultural patterns (e.g., socio-political organization, trade interactions, etc.). New terminologies related to cultural history and artifact typology should not be avoided but encouraged if they are understood to be tentative and directed toward theory building. Just as important as the above is the encouragement of new research deepening old data in areas of chronology (e.g., radiocarbon dating), subsistence, etc. The Research Group should serve as a sounding board for developing ideas...

Tom

Perttula subsequently drafted a letter of invitation to the first group of about 18 individuals encouraging their participation in the research group.

\section{MEETINGS OF THE EAST TEXAS CADDO RESEARCH GROUP (ETCRG)}

The ETCRG has met eight times between 1996 and 2008. In the remainder of this article, we provide a brief summary of the various meetings.

The first meeting of the ETCRG was held over lunch at a Natchitoches, Louisiana, restaurant on March 30, 1996, during the $38^{\text {th }}$ Caddo Conference.
We brainstormed about the organization of the group while feasting on meat pies and craw fish. No specific research topic for the group to focus on was discussed at the meeting. We did not maintain a list of attendees of this meeting, but remember that Bob Turner, at least, joined us at the lunch.

One of our most productive meetings was the second session of the ETCRG held on Sunday morning, October 27, 1996, at the Annual Meeting of the Texas Archeological Society in San Antonio, Texas. The meeting was well attended, but again we do not have a list of attendees. Dee Ann Story and Cecile Carter were major respondents to the presentations, however. A tape was made of the proceedings, but the audio quality was very poor, and consequently it has not been fully transcribed and/or published; a partial transcript has been typed but not published. The meeting considered the character of the Middle Caddo archaeological record of East Texas in its broadest geographical sense-occasioned at least in part by current research in the region, most especially the recent excavations at the Oak Hill Village site in Rusk County, Texas (see Rogers and Perttula 2004) — by reviewing major research findings along specific thematic lines (settlement, subsistence, dating, mounds, mortuary practices, ceramic traits, etc.) in each of several river basins. Summary handouts were prepared by the presenters: Maynard Cliff (lower Sulphur River Basin), Bo Nelson and Mike Turner (Big Cypress Creek Basin), Tim Perttula and Brett Cruse (the upper and middle Sabine River basin), Tim Perttula (middle Red River and upper Sulphur River basins), and Tom Middlebrook (Angelina and Attoyac River basins). Jim Corbin (Washington Square Mound Site) and Bob Turner (three Middle Caddo cemeteries in Camp and Upshur counties) discussed specific Middle Caddo sites in the region. An summary of the meeting was prepared by Middlebrook and Perttula (1997:1-8) in Volume 9/1997 of the Journal of Northeast Texas Archaeology, along with two articles on the Middle Caddo period archaeology in the lower Sulphur and Sabine River basins (see Appendix). Five additional articles appeared in Volume 10/1997 of the Journal of Northeast Texas Archaeology related to this second meeting of the ETCRG (see Appendix).

The $3^{\text {rd }}$ meeting of the ETCRG was held at Legends Restaurant from 5:30-7:30 P.M. on March 14, 1997, in Norman, Oklahoma during the $39^{\text {th }}$ Caddo Conference. Recorded attendees included: Tim Perttula, Tom Middlebrook. Gloria and Bob Turner, Maynard Cliff, Mike Turner, Bo Nelson, 
Melinda Tate, David Jeane, Patti Haskins, Mark Walters, Wildena Guy Moffer, Cecile Carter, Stacy Halfmoon, Rolf Moore, Jeff Girard, and Pete Thurmond. Much of the session involved a presentation by Maynard Cliff reviewing ceramic analysis and typology in the Caddo area. He provided extensive handouts and review articles. Other items listed on the pre-circulated agenda for discussion included: Caddo houses (Bob Skiles), the use of celts (Jeff Girard), and future Middle Caddo period topics (Tim Perttula and Tom Middlebrook); further discussions of the Middle Caddo period at the ETCRG have not taken place. Again, a poor quality tape was made of the session, but no transcript was ever produced or published.

The next day, Perttula and Middlebrook did discuss the Middle Caddo period and the activities of the ETCRG as part of the program at the $39^{\text {th }}$ Caddo Conference.

A brief informal session of the ETCRG was held on Sunday morning, October 25, 1998, at the Annual Meeting of the Texas Archeological Society in Waco, Texas. Listed attendees included: Tim Perttula, Tom Middlebrook, Maynard Cliff, Bo Nelson, Cecile Carter, Bob and Gloria Turner, Patti Haskins, and Mark Walters. Unfortunately, there are no notes regarding the topics that were discussed at this informal meeting.

Up until the $5^{\text {th }}$ ETCRG meeting, our notes and records on our past meetings had been generally lacking in substantive details on what had transpired, who had attended/participated, or what the future plans of the ETCRG might be. Things began to improve with the $5^{\text {th }}$ ETCRG. Leading up to the next ETCRG meeting proposed in March 1999, we sent out invitations in January 1999 to East Texas Caddo archaeologists soliciting their participation in the ETCRG:

January 10, 1999

RE: East Texas Caddoan Research Group

Dear

You are invited to participate in the upcoming workshop sponsored by the East Texas Caddoan Research Group to be held on March 12 ${ }^{\text {th }}$ during the 1999 Caddo Conference in Jefferson, Texas, on March 12-13. The six hour workshop will address current formulations of Caddoan development through time by focusing on three general regions of East Texas (Northern
Section-roughly the Red and Sulphur drainages, Central Section-Cypress and Sabine drainages, and Southern SectionAngelina and Neches drainages). You are asked to address the __ Section, but you may adjust the boundaries of your study area in any way you see fit. You are requested to summarize the Caddoan cultural history in your area and provide suggestions of cultural-taxonomic units based on chronological and distributional data. Additionally, please discuss the key research questions that could refine our understanding of Caddoan archeology in your area. You are encouraged to construct maps illustrating your ideas or speculations of cultural-taxonomic unit distributions through time and highlighting key sites. Please feel free to bring illustrative artifacts, photos, slides, or other hands-on materials to stimulate discussion. You are asked to (1) present a 20 minute informal talk followed by open round table discussion during the workshop, and (2) provide a 2 page summary of your remarks suitable for publication in the proceedings. Please notify one of the ECRG coordinators below concerning your willingness to participate as soon as possible and not later than February 1,1999 . We look forward to hearing from you during this stimulating workshop.

Tim Perttula

10101 Woodhaven Dr.

Austin, Texas 78753

E-mail: tkpfnta@ix.netcom.com

512-873-8131

Tom Middlebrook

4218 Mystic Ln.

Nacogdoches, Texas 75961

E-mail:TMdlbrk@aol.com

409-560-6733

We received enough positive responses that the $5^{\text {th }}$ meeting of the ETCRG was held on March 12, 1999, during the $41^{\text {st }}$ Caddo Conference in Jefferson, Texas. The ETCRG was one of the sponsors of the Conference, along with the Friends of Northeast Texas Archaeology (the publishers of the Journal of Northeast Texas Archaeology).

A tape recording was not made of the ETCRG meeting, which was held as a workshop in a separate 
facility from the Caddo Conference itself (Davis and Davis 2009). Attendees included: Tom Middlebrook, Mark Walters, Bo Nelson, Cecile Carter, Lissa Toboh, Helen Tanner, Macky McIntosh, Eric DeLaughter, Alex Barker, Vernon Holcomb, David McGee, Tom Walker, William McIntosh, Victor Galan, Todd McMakin, Suzanne Stallings, Rosemary Bergeron, Jeff Girard, Ross Fields, Gloria and Bob Turner, Steven Moore, David Jeane, and Nancy Kenmotsu. During the course of the meeting, Alex Barker presented research findings regarding the occurrence of shell gorgets in the Caddo archaeological area. Summaries of current formulations of regional cultural history were presented by Bob Turner ( $\mathrm{Cy}-$ press Creek Basin) and Ross Fields (Upper Sulphur River Basin and Cooper Lake). These presentations were never published, however, and we still had the feeling that the ETCRG had not gotten off the ground as a useful research group. We suspect that the hiatus between the $5^{\text {th }}$ and $6^{\text {th }}$ ETCRG meetings was due in large part to our inability to articulate what we wanted the group to accomplish as well as the difficulty in organizing a group of archaeologists to focus on specific ETCRG-directed topics/themes that have their own research agendas and research commitments.

The ETCRG next met after a seven year hiatus. Our purpose in meeting again was to discuss the historic archaeology of the Caddo peoples in East Texas and adjacent Northwest Louisiana. The $6^{\text {th }}$ ETCRG meeting was held December 2-3, 2006, in Nacogdoches, Texas, on the campus of Stephen F. Austin State University. We chose to focus on the period after ca. A.D. 1542 to encourage, in light of recent findings and ongoing archaeological research, the consideration and development of a better regional understanding of the Caddo archaeological record in East Texas following European contact (Perttula and Middlebrook 2007:1-7), as well as better understand (as seen through the archaeological record) the nature of interaction between the Caddo peoples in East Texas and Northwest Louisiana and Europeans (cf. Barr 2007). The various presentations (with maps, images, and hands-on materials) were followed by an open round table discussion where information was shared and archaeological questions and problems were posed and further considered by the group as a whole.

Attendees at the meeting, moderated by Middlebrook and Perttula, included Tom Middlebrook, Tim Perttula, Bo Nelson, Mark Walters, Shawn Marceaux, George Avery, Jeffrey M. Williams, Jay
Blaine, Jerrylee Blaine, Jeff Girard, Victor Galan, Robert Turner, Maynard B. Cliff, and David Jeane.

The 2006 ETCRG meeting was wide-ranging and varied. Most of the discussions focused on particular Historic Caddo archaeological sites and their general material culture character, but the meeting ended with questions concerning future directions in the study of the Historic Caddo archaeological record (Perttula and Middlebrook 2007:3-5). The participants in the meeting were sufficiently encouraged in the character and scope of the discussions and presentations (a number of presentations from this meeting were subsequently published in Volume 26/2007 and 28/2008 of the Journal of Northeast Texas Archaeology, see Appendix), that all agreed that the ETCRG should meet again in a year's time.

The $7^{\text {th }}$ ETCRG meeting was held in Nacogdoches on December 8-9, 2007. Attendees at this meeting included Tom Middlebrook, Morris Jackson, Tim Perttula, Chet Walker, Shawn Marceaux, Duncan McKinnon, Bo Nelson, Mark Walters, Jeffrey M. Williams, Jeff Girard, George Avery, Mark Armstrong, Ross Fields, and Leslie Cecil.

This meeting continued the focus of the ETCRG on the Historic Caddo archaeological record in East Texas, as we had not exhausted topics arising out of the 2006 ETCRG meeting that were worthy of presentation and discussion. The range of presentations, some of which have been published (see Appendix) included the following:

a summary of recent findings from the Pine Tree Mound site (41HS15), in Harrison County, Texas, and the possibility that this site may be part of the Nondacao province encountered by the De Soto entrada in 1542 (Ross Fields);

a discussion of the known Historic Caddo archaeological record in the Red and lower Sulphur River areas (Timothy K. Perttula);

an update on a study of Historic Caddo ceramics from sites in the Neches and Angelina river basins (Shawn Marceaux);

a review of the character of the Caddo ceramic assemblage and European material culture from Mission San Jose de los Nasonis (1716-1719, 1721-1730, 41RK200) (Timothy K. Perttula and Shawn Marceaux); 
the possible meaning in the patterns in colors of glass beads on aboriginal Caddo and non-Caddo sites in the region (George Avery);

reports on geophysical surveys on $16^{\text {th }}$ and $17^{\text {th }}$ century Caddo sites on the Red River, including parts of the Hatchel site (41BW3) known as the Hill Farm site (41BW169), by Chet Walker, and a spatially large geophysical survey at the Battle Mound (3LA1), by Duncan McKinnon. The results of these important geophysical surveys have been recently published by Perttula et al. (2008) and McKinnon (2008);

Mark Armstrong discussed archaeological findings from survey and metal detecting work at $41 \mathrm{HS} 840$, a possible 1830 s Caddo Indian or Coushatta Indian settlement;

Jeff Williams discussed the exciting results of his GIS-aided archaeological and historical research of the El Camino Real de los Tejas in East Texas, with a particular focus on the regional landscape and river crossings (see Williams 2007);

a presentation by Morris Jackson on archival and map research relating to the search for Presidio Nuestra Senora de los Dolores de los Tejas (1716-1719, 1721-1730) and Mission Purisima Concepcion (1716-1719, 1721-1729), presented in conjunction with an update by Tom Middlebrook on the results of recent archaeological survey designed to identify these Spanish sites. At the moment, they have eluded discovery; and

a detailed presentation by Tom Middlebrook on the exciting archaeological findings from work he and Morris Jackson have been leading on the Plaza Principal (41NA303) in downtown Nacogdoches. This work has exposed and excavated a number of discrete archaeological features dating from the mid- $18^{\text {th }}$ century to the early part of the $19^{\text {th }}$ century, and during the course of that work they have gathered an impressive sample of Spanish Colonial and aboriginal artifacts for this period, as well as well-preserved animal remains.

The $8^{\text {th }}$ ETCRG meeting was held December 6-7, 2008, on the campus of Stephen F. Austin State
University in Nacogdoches, Texas. Participants included Jeff Girard, Tom Middlebrook, Morris Jackson, Jeff Williams, George Avery, Bo Nelson, Jim Tiller, Shawn Marceaux, Tim Perttula, Velicia Bergstrom, Bob Turner, Chet Walker, Duncan McKinnon, Mark Walters, and Jay Blaine.

Two topics or themes were the focus of the $8^{\text {th }}$ ETCRG: Caddo Origins and Caddo historic archaeology in East Texas. The latter topic was a continuation of discussions on the character of the Caddo historic archaeological record in the region from the $6^{\text {th }}$ and $7^{\text {th }}$ ETCRG, while the Caddo origins topic arose during conversations between participants as the $8^{\text {th }}$ ETCRG was being organized and planned.

Jeff Girard developed the Caddo origins topic for the ETCRG participants by outlining a series of issues and questions worth consideration. These included "Basic Definitional Problems," "Chronology," "Social, Political, and Economic Integration," "Social and Political Hierarchies," and "Theoretical Perspectives." He also reviewed the archaeological context of Caddo origins, or the early development of Caddo Culture, in northwestern Louisiana, focusing on key sites and phases spanning the period from ca. A.D. 400-1050, along with information on the material culture (particularly ceramics) of Woodland and early Caddo sites in this region.

The discussion by ETCRG participants of Jeff's issues was wide-ranging, once we agreed that it was very difficult to specify those specific traits that would be considered diagnostic of Caddo culture, particularly early Caddo culture. From this, we considered how we could arrive at a material culture characterization of Caddo groups and peoples in the Caddo archaeological area, recognizing that the Caddo tradition includes elites vs. common folk, each having a different material culture make-up. Other issues that were considered included CaddoCahokia connections (possible, but difficult to identify); the organizational complexity of early Caddo groups, and the question of competing polities; mortuary comparisons and elite regalia; the idea of shaft tombs as a unique early Caddo mortuary practice; dating and chronological issues; and the spatial and temporal variability in early Caddo culture.

Other Caddo Origins presentations included the following:

Chet Walker provided an overview of the geophysical findings at the early Caddo George C. Davis mound center (41CE19). This work has resulted for the first time in 
an archaeological view of the organization of an early Caddo mound center community on the landscape, and has demonstrated that there are probably hundreds of Caddo structures present on the site over the ca. A.D. 850-1300 occupation there;

Mark Walters provided a perspective from the middle reaches of the Sabine River (Smith and Upshur counties) on the character of both Woodland and early Caddo habitation and mound sites, focusing on the Browning site (41SM195), a late Woodland Mill Creek Culture site;

The Mast site (41NA157) was the focus of a presentation by Tom Middlebrook, and led to a consideration of the Woodland/Caddo transition in the East Texas Pineywoods. The Mast site is primarily a Mossy Grove Woodland site with plain sandy paste (Goose Creek Plain, var. unspecified) pottery, dart points, and burned rock features; it is undated by radiocarbon at the present time, and no report on the excavations by Stephen F. Austin State University has been prepared. The site has no midden, and was perhaps seasonally occupied. The consensus of the ETCRG participants was that to learn more about the local archaeological record during Woodland and early Caddo times it would be important to focus on lifeways as can be detected in the archaeological deposits, and less on the specifics of material culture or cultural-taxonomic identifications;

The Devils Ford Creek site (41SB157) is a late Woodland Mossy Grove culture site excavated by the U.S. Forest Service in 1999; no report has been published on this work. Velicia Bergstrom provided an overview of the archaeological findings;

Timothy K. Perttula focused on the Caddo origins issue by discussing the archaeological findings from the Boyette site (41NA285) at Lake Naconiche (Perttula 2008). Here, excavations have identified a Late Woodland component that dates from cal AD 667-847, followed by an early Caddo component that dates from cal AD 873-1075; the latter is contemporaneous with the Alto phase, but is not a component of that phase or part of the same cultural group, but part of a separate Caddo com- munity. Characteristics of the material culture record (especially the sandy paste or tempered ceramic wares) suggest stylistic and technological similarities between the two components, rather than a stylistic and technological replacement (which would be expected if the Woodland and early Caddo groups were not related). Perttula views the $7^{\text {th }}$ to early $9^{\text {th }}$ century Woodland population to be directly antecedent or ancestral to the $9^{\text {th }}-11^{\text {th }}$ century Caddo population that lived at the Boyette site.

Our consideration of Caddo origins concluded with a discussion of the direction the ETCRG could proceed in arriving at a more current and broader understanding of Late Woodland and early Caddo populations and lifeways, and develop a more nuanced perspective on Caddo origins. One issue that was raised was our need to better appreciate what was taking place among other aboriginal groups at that time (ca. A.D. 700-1050) - and what "influences" or cultural practices might have been in play-particularly in the Lower Mississippi Valley, Cahokia, the Texas and Louisiana Gulf Coast, Toltec, and the Arkansas River valley (i.e., Spiro area). Future discussions of Caddo origins might profit by including archaeologists that are actively conducting archaeological research in these areas during the relevant temporal period. It was also agreed that it was important for ETCRG participants to work together to compile up-to-date archaeological information relevant to Caddo origins, including: material culture attributes and assemblages (i.e., ceramics, celts, chipped stone tools); mound constructions; mortuary rituals and regalia; kinds of structures found in ceremonial and domestic contexts; and absolute dates of sites and key features. Finally, ETCRG participants agreed that it is important to identify key sites thought to date between ca. A.D. 700-1050 that have the potential, through future work, to possess archaeological deposits of the appropriate age and character to directly contribute relevant archaeological information on Caddo origins. Some sites mentioned in this regard included James Pace (16DS268), Bowman (3LR46), Boxed Spring (41UR30), Hale (41TT12), and Fasken (41RR14) in northwestern Louisiana, southwestern Arkansas, and East Texas.

The Historic Caddo archaeology topic discussion in the $8^{\text {th }}$ ETCRG meeting was initiated by Jeff Williams, whose presentation was entitled "Research on El Camino de los Tejas." This was an overview of 
research conducted to date, and the need to identify high potential significant sites along the trail, including historic Caddo sites. The idea was broached that the ETCRG work together through a National Park Service challenge cost share grant to locate and document such sites, in conjunction with involvement from the Caddo Nation of Oklahoma, but no consensus or plan of action was reached on how to do that.

Further presentations on Historic Caddo archaeology at the $8^{\text {th }}$ ETCRG included:

George Avery's presentation concerned 2008 archaeological investigations (primarily shovel testing) in a small area of mission-era deposits at Mission Dolores (41SA25) in San Augustine, Texas. This work was done as part of a planned mission replication project at the site;

Jim Tiller talked at length, accompanied with many maps, on the subject of the location of a number of early $19^{\text {th }}$ century Caddo villages along the Texas-Louisiana border, including four villages (North Caddo, Middle Caddo, Big Spring, and South Caddo) in what is now Harrison County, Texas (see also Tiller 2008). He laid out the case that the $19^{\text {th }}$ century Caddo village known as Timber Hill, Dehahuit's Timber Hill, is in actuality the North Caddo Village along Haggerty's Creek and Trammel's Trace. None of these villages have yet to be conclusively identified through archaeological investigations, however;

Duncan McKinnon provided further information on the archaeo-geophysical survey investigations he has recently completed at the Battle site (3LA1) in the Great Bend area of the Red River. A wide variety of habitation features and possible burial areas have been identified in this work. Future plans here include continued geophysical survey in new areas at the site, conduct landscape geomorphological studies, archaeologically test identified geophysical anomalies, and synthesize the findings from the 1948 excavations at the site by Alex D. Krieger and Lynn Howard;

The J. T. King (41NA15) site is an historic Caddo village in the Angelina River basin in western Nacogdoches County, situated on the northern route of the Camino Real de los Tejas, about $5 \mathrm{~km}$ east of the Angelina River. Tom Middlebrook discussed recent archaeological investigations (surface collection, shovel testing, and $1 \times 1 \mathrm{~m}$ units) he carried out at the site, focusing particularly on the character of the aboriginal ceramics (dominated by grog-tempered brushed utility wares and Patton Engraved fine wares), as well as the lithics (predominantly on non-local cherts, including triangular arrow points); a cupreous tinkler was recovered from one of the $1 \mathrm{x} 1 \mathrm{~m}$ units. Based primarily on the kinds and proportions of decorated sherds in the J. T. King site ceramic assemblage, Middlebrook suggested that the Caddo occupation is a component of the Deshazo subcluster within the ca. 1720 Anderson cluster (cf. Corbin 2007:19-20);

Chet Walker next discussed the utility of an EM-61 geophysical instrument as a means for efficiently locating metal artifacts in archaeological deposits on Historic Caddo sites in East Texas; and

Timothy K. Perttula ended the discussion of the Historic Caddo archaeology topic for the $8^{\text {th }}$ ETCRG with a consideration of the diversity in late $17^{\text {th }}-18^{\text {th }}$ century ceramics on key Caddo sites in Nacogdoches County with well-studied assemblages, namely: Henry M. (41NA60, see Middlebrook and Perttula 2008), Deshazo (41NA27, Story 1995), and Spradley (41NA206), as well as other sites documented by Middlebrook (2007). Those analyses indicated that the Henry $M$. site and the Deshazo site are ceramically most similar; Bayou Loco and Angelina River sites are dominated by brushed utility wares; the Lanana Creek, Legg Creek, and Attoyac Bayou sites are part of a different local Caddo ceramic tradition. Finally, five distinct groupings of Historic Caddo sites can be defined employing various ceramic attributes, and these groupings may represent sites occupied by different and socially distinct Caddo communities.

\section{CONCLUSIONS}

The success of the last three ETCRG meetings has put the ETCRG on firm ground as a viable 
venue in which to discuss in detail-but in an informal setting - research issues, problems, and findings concerning East Texas Caddo archaeology. As long as there is a group of dedicated Caddo archaeological researchers that continue to work in the East Texas region, we hope that this group will remain a productive way in which to improve our understanding of the prehistory and history of the Caddo peoples.

As we write this, plans are afoot to hold the next, and $9^{\text {th }}$, ETCRG meeting in Nacogdoches, Texas, in 2009. The focus of the meeting has yet to be determined.

\section{ACKNOWLEDGMENTS}

First, we thank all of the various ETCRG meeting attendees, who came and actively participated in the meetings. We would also like to thank George Avery, Bo Nelson, and Duncan McKinnon for commenting on an earlier version of this article.

\section{REFERENCES CITED}

Barr, J.

2007 Peace Came in the Form of a Woman: Indians and Spaniards in the Texas Borderlands. University of North Carolina Press, Chapel Hill.

Corbin, J. E.

2007 Cultural Diversity in the Southern Caddo Region. Journal of Northeast Texas Archaeology 26:11-23.

Davis, H. A. and E. M. Davis

2009 An Account of the Birth and Growth of Caddo Archeology, as Seen by Review of 50 Caddo Conferences, 1946-2008. Caddo Archeology Journal 19:3-72.

Lee, D.

2008 50 th Caddo Conference: A Retrospective. Natchitoches, Louisiana 2008. The Louisiana Regional Folklife Program, Williamson Museum, The Louisiana Regional Archaeology Program, and Northwestern State University of Louisiana.

McKinnon, D. P.

2008 An Archaeogeophysical Analysis of Central Caddo Settlement Patterning at Battle Mound (3LA1). Master's thesis, Department of Anthropology, University of Arkansas, Fayetteville.
Middlebrook, $\mathrm{T}$.

2007 A Survey of Historic Caddo Sites in Nacogdoches County, Texas. Journal of Northeast Texas Archaeology 26:99-115.

Middlebrook, T. and T. K. Perttula

1997 The Middle Caddoan Period in East Texas: A Summary of the Findings of the East Texas Caddoan Research Group. Journal of Northeast Texas Archaeology 9:1-8.

2008 Archaeological Investigations at the Henry M. Site (41NA60): An Early Historic Caddo Farmstead in Nacogdoches County, Texas. Journal of Northeast Texas Archaeology 28:13-20.

Perttula, T. K. (editor)

2008 Lake Naconiche Archeology, Nacogdoches County, Texas: Results of the Data Recovery Excavations at Five Prehistoric Archeological Sites. 2 Vols. Report of Investigations No. 60. Archeological \& Environmental Consultants, LLC, Austin.

Perttula, T. K. and T. Middlebrook

2007 Historic Caddo Archaeology: An Occasional Meeting of the East Texas Caddo Research Group, December 2-3, 2006, in Nacogdoches, Texas. Journal of Northeast Texas Archaeology 26:1-7.

Perttula, T. K., C. P. Walker, and T. C. Schultz

2008 A Revolution in Caddo Archaeology: The Remote Sensing and Archaeological View from the Hill Farm Site (41BW169) in Bowie County, Texas. Southeastern Archaeology 27(1):93-107.

Rogers, R. and T. K. Perttula

2004 The Oak Hill Village (41RK214), Rusk County, Texas. Document No. 030083. PBS\&J, Austin.

Story, D. A. (editor)

1995 The Deshazo Site, Nacogdoches County, Texas, Volume 2: Artifacts of Native Manufacture. Studies in Archeology 21. Texas Archeological Research Laboratory, The University of Texas at Austin.

Tiller, J.

2008 Was Timber Hill the Last Caddo Village in the Caddo Homeland? Caddo Archeology Journal 18:11-21.

Williams, J. M.

2007 GIS Aided Archaeological Research of El Camino Real de Los Tejas with Focus on the Landscape and River Crossings along El Camino Carretera. Masters of Spatial Science, Stephen F. Austin State University, Nacogdoches. 


\section{APPENDIX, PUBLICATIONS ARISING DIRECTLY FROM THE EAST TEXAS CADDO RESEARCH GROUP MEETINGS}

Avery, G.

2008 Seed Bead Color Patterns from Colonial Period Sites in Texas and Louisiana. Journal of Northeast Texas Archaeology 28:57-63.

Cliff, M. B.

1997 The Middle Caddoan Period in the Lower Sulphur River Area. Journal of Northeast Texas Archaeology 9:9-16.

Fields, Ross C.

2008 The Pine Tree Mound Site and the Entrada of the Hernando De Soto Expedition of 1542. Journal of Northeast Texas Archaeology 28:1-8.

Girard, J. S.

2007 Sites in Northern Louisiana with Major Collections of Historic Caddo and other Native American Pottery. Journal of Northeast Texas Archaeology 26:24-32.

Gregory, H. F. and G. Avery

2007 American Indian Pottery from Historic Period Sites in North Louisiana. Journal of Northeast Texas Archaeology 26:33-76.

Marceaux, P. S.

2007 Recent Research on the Archaeological and Historical Evidence of the Hasinai. Journal of Northeast Texas Archaeology 26:82-98.

Middlebrook, $\mathrm{T}$.

1997 The Caddoan Occupation of the Attoyac and Angelina River Basins in the Middle Caddoan Period. Journal of Northeast Texas Archaeology 10:36-40.

2007 A Survey of Historic Caddo Sites in Nacogdoches County. Journal of Northeast Texas Archaeology 26:99-115.

Nelson, B. and M. Turner

1997 Middle Caddoan Sites in the Cypress Creek Drainage Basin. Journal of Northeast Texas Archaeology 10:1-11.

Perttula, T. K.

1997a Middle Caddoan Period Archaeology in the Upper Sulphur River Basin. Journal of Northeast Texas Archaeology 10:41-46. 1997b The Archaeology of the Middle Caddoan Period in the Middle Red River Valley of Northeast Texas. Journal of Northeast Texas Archaeology 10:47-51.

2007a Points of Discussion and Directions for Research on Caddo Historic Archaeology. Journal of Northeast Texas Archaeology 26:8-10.

2007b One Attempt at Defining Allen Phase Ceramic Subclusters. Journal of Northeast Texas Archaeology 26:77-81.

2007c Upper Neches River Basin Caddo Ceramics, an Attempt at an Updated Seriation and a Context for Understanding Frankston to Allen Phase Ceramic Stylistic and Technological Changes. Journal of Northeast Texas Archaeology 26:154-158.

2008a Historic Caddo Archaeology on the Red and Lower Sulphur River Areas of Northeast Texas. Journal of Northeast Texas Archaeology 28:25-34.

2008b Trends and Varieties in Late Caddo and Historic Caddo Fine Ware Pottery Types in the Upper Neches River Basin. Journal of Northeast Texas Archaeology 28:51-55.

Perttula, T. K. and J. B. Cruse

1997 The Caddoan Archaeology of the Sabine River Basin during the Middle Caddoan Period. Journal of Northeast Texas Archaeology 9:30-37.

Perttula, T. K., B. Young, and P. S. Marceaux

2009 Caddo Ceramics from an Early $18^{\text {th }}$ Century Spanish Mission in East Texas: Mission San Jose de los Nasonis (41RK200). Journal of Northeast Texas Archaeology 29:81-89.

Turner, R. L.

1997 Observations on Four Probable Middle Caddo Cemeteries in Camp and Upshur Counties. Journal of Northeast Texas Archaeology 10:12-35.

2008 Pottery from 41NA202: The Stephens Site in Nacogdoches County, Texas. Journal of Northeast Texas Archaeology 28:9-11.

Walters, $\mathrm{M}$.

2007 Late Titus Phase Sites along Caney Creek in Northern Wood County, Texas. Journal of Northeast Texas Archaeology 26:145-149. 